\title{
TREATMENT OF RHEUMATOID ARTHRITIS BY INTRAMUSCULAR TRIAMCINOLONE ACETONIDE AND TRIAMCINOLONE DIACETATE
}

\author{
BY
}

\author{
JACK ZUCKNER
}

Section on Arthritis, Department of Medicine, Saint Louis University School of Medicine and the University Hospital (Firmin Desloge Hospital), Saint Louis, Missouri

The results of a study (Zuckner, 1961) evaluating the therapeutic response of intra-articularly administered triamcinolone acetonide* (hereafter referred to as TActn) and triamcinolone diacetate* (TDac) suggested that large doses of these hormones had a profound systemic effect. The injection of either of these hormones in a dose of $100 \mathrm{mg}$. into a knee joint affected by rheumatoid arthritis resulted in a generalized anti-inflammatory response, including improvement in other inflamed joints as well as that injected. This generalized improvement usually persisted for 2 to 3 weeks. These favourable findings led to further study with these steroids, utilizing the more practical intramuscular route of administration.

\section{Procedure}

The acetonide and diacetate derivatives of triamcinolone were injected intramuscularly into 36 patients with rheumatoid arthritis. There were 112 injections, 68 of TActn and 44 of TDac. The dose per injection was $100 \mathrm{mg}$. These steroids were compared with hydrocortisone acetate (FAc) given by intramuscular injection in the same patients; there were seven injections of the $100 \mathrm{mg}$. dose of FAc, and eleven of $500 \mathrm{mg}$.

Patients were examined once a week at first in most instances, less often later. Subjective improvement in pain and stiffness and objective evidence of tenderness, heat, swelling, range of motion, capsular thickening, and fluid in involved articulations were determined and an estimated composite percentage recorded. These signs and symptoms were evaluated at each visit. The interval between injections was usually determined by the patient's subjective response, particularly the manifestation of pain. An effort was made to maintain at

* Supplied by Lederle Laboratories Division, American Cyanamid Company, Pearl River, New York. least 50 per cent. improvement as determined by the estimated composite figure. The triamcinolone steroid $\vec{s}$ were administered in rotation for the most part.

Clinical evidence of toxicity was sought at each visit Observations were made for moon facies, hirsutism $\overline{3}$ ecchymoses, blood pressure changes, body weight oedema, and other possible alterations. Laboratory procedures included urine analyses, blood counts, ख्रdo erythrocyte sedimentation rates (Westergren). These were performed at varying intervals, usually the davof an injection and one week later at the beginning of study, and less frequently afterwards.

Other therapeutic measures were continued withoū modification with the exception of orally-administere娄 steroids. 23 patients were receiving such medicatio when the study was instituted, and an additional thre patients were taking steroids orally at other times during the study. In nineteen individuals the oral dose of steroid was lowered, and in ten of these it was completel discontinued. 28 patients were receiving gold sal therapy (gold sodium thiomalate or gold thioglucose) in eight of these individuals the gold was begun at the time of the first steroid injection. Twelve patients has already received more than $700 \mathrm{mg}$. gold salt befor the first intramuscular injection of a triamcinolone derivative; in two others, the total dose of gold salt was between 500 and $600 \mathrm{mg}$. at the start of the study.

The duration of observation varied; seventeen patients were studied for 100 or more days, and six of these for approximately one year. The remaining nineteen patients. were observed for an average of about 70 days each.

\section{Results}

The anti-inflammatory response to intramuscula injections of triamcinolone acetonide (TActn) and triamcinolone diacetate (TDac) was satisfactory in most patients. Improvement was considered satisfactory if there was at least 50 per cent. relief o the non-permanent clinical manifestations of tho 
disease for a period of 7 or more days after an injection. 83 per cent. of the patients showed such benefit at some time during treatment with TActn and 80 per cent. had similar results with TDac (Table I). When the results of individual injections were analysed, approximately 73 per cent. of injections with either TActn or TDac were followed by a satisfactory response. The average duration of improvement after an injection was 20.2 and 16.2 days for TActn and TDac respectively; the maximum period of relief after an injection was 69 and 75 days respectively. When these results were compared with those which followed the intramuscular injection of hydrocortisone acetate (FAc) in doses of 100 and $500 \mathrm{mg}$., the latter steroid proved inferior (Table I). The 100-mg. dose of FAc was almost completely ineffective by comparison, and the 500-mg. dose gave significantly poorer results. The average duration of improvement with the 500-mg. dose of FAc was $5 \cdot 2$ days, and six injections were followed either by no improvement or by not more than 3 days of benefit. The maximum period of relief was 17 days with this $500-\mathrm{mg}$. dose. The 100-mg. dose of FAc was followed by an average of $1 \cdot 1$ days of improvement.

TABLE I

RESULTS WITH INTRAMUSCULAR INJECTIONS OF TRIAMCINOLONE ACETONIDE (TActn), TRIAMCINOLONE DIACETATE (TDac), AND HYDROCORTISONE ACETATE

(FAc) IN PATIENTS WITH RHEUMATOID ARTHRITIS

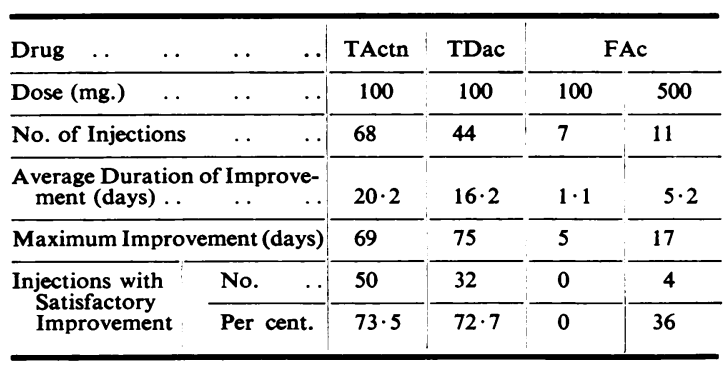

A comparison of the relative efficacy of the triamcinolone derivatives in individual cases was made in fourteen patients who received at least two injections each of TActn and TDac. Fewer injections in a patient were not satisfactory for evaluation because of the wide variability in improvement sometimes observed from one injection to the next. Thus, it was possible for one injection of either of the triamcinolone steroids to give very satisfactory results, and for this to be followed by a very poor response to the next injection of the same drug. Causative factors for this variability in response (such as an obvious change in the course of the disease or an increase in physical activity) were not apparent. In patients in whom suitable comparisons were made, ten derived greater benefit from TActn, and four had more improvement from TDac.

Patients receiving gold salts simultaneously with intramuscular steroid therapy were divided into two groups for analysis:

(1) Those who were either beginning gold salt therapy or who had received a total dose of less than $700 \mathrm{mg}$. when intramuscular steroid injections were started;

(2) Those who had a total dose greater than $700 \mathrm{mg}$. during the period of intramuscular hormone administration.

Four patients initially in the first group (less than $700 \mathrm{mg}$.) had received enough gold salt by the end of the study to fall into the second group (more than $700 \mathrm{mg}$. gold salt) making a total of sixteen patients in each group. This division into two groups was done to evaluate any possible effect of gold salts on the results. The separation at the $700-\mathrm{mg}$. total dose level was selected on the assumption that total doses greater than this would be less likely to influence the improvement attained from one injection of steroid to the next. There were 23 injections of TActn and fifteen injections of TDac in the group that received less than $700 \mathrm{mg}$. gold salt and these resulted in improvement after each intramuscular steroid injection averaging 23.4 and 15.9 days respectively. In the second group, there were 31 injections of TActn which resulted in an average duration of improvement after each injection of 19 days, and twenty injections of TDac, followed by improvement averaging $16 \cdot 6$ days. Simultaneous treatment with gold salts apparently had no significant effect on the results.

The average daily maintenance dose of orally administered steroids at the beginning of the study was equivalent to $7.5 \mathrm{mg}$. triamcinolone (free alcohol form, hereafter referred to as triamcinolone). Sixteen patients were receiving triamcinolone orally, three dexamethasone, two prednisone, and two 6-methyl prednisolone. Dosages of the latter steroids were converted to triamcinolone dosages for evaluation purposes, using the following dosage ratios:

triamcinolone : dexamethasone : prednisone : 6-methyl prednisolone

At the end of the period of observation, the average daily maintenance dose was equivalent to $4 \mathrm{mg}$. triamcinolone. 
The total daily steroid dose, that is, the daily oral maintenance dose plus the daily intramuscular dose (the latter obtained by dividing the dose of steroid injected intramuscularly by the days of satisfactory improvement) was determined at the end of the study and compared with the daily oral maintenance dose initially. To balance the doses of TActn and TDac, it was assumed that these steroids when given intramuscularly were equivalent $\mathrm{mg}$. for $\mathrm{mg}$. to the orally-administered free alcohol form of triamcinolone. Thus, of nineteen patients in whom an attempt was made to lower the oral steroid dose, there were ten in whom the total oral plus intramuscular dose daily at the end of the study was greater than the original oral dose daily; and in two the comparative doses for each period were equal. In seven patients the total oral plus intramuscular dose daily at the end of the period of observation was less than the daily oral dose at the beginning. These seven patients had a daily oral maintenance dose of triamcinolone initially of $7 \cdot 3 \mathrm{mg}$. as compared with the combined oral plus intramuscular dose daily at the termination of the study of $4.5 \mathrm{mg}$.

The onset of improvement after the intramuscular administration of TActn and TDac was usually first noted on the morning after an injection. At times, patients described improvement beginning 3 to 5 hours after an injection, and less frequently, 48 hours after an injection. In some cases the improvement was gradual over a few days, but most often, maximum improvement developed by the day following the injection and then would persist as such for approximately 2 to 3 weeks.

Eleven patients showed marked subjective and objective improvement as compared with results from previous methods of therapy, including relatively much larger doses of steroids administered orally in some. One patient (A.R.A. Classification II, III: Steinbrocker, Traeger, and Batterman, 1949) has been free of objective evidence of synovitis and almost completely asymptomatic for a period of 70 days after only one injection of TActn, whereas, she previously had marked $(3+)$ activity and synovitis continuously for 3 years before the injection.

The side-effects of TActn and TDac injected intramuscularly are recorded in Table II (opposite). Many of these are similar to those noted with orally administered steroids. Since 23 patients were taking steroids orally at some time during the study, it was difficult to evaluate hormonal reactions in these individuals as those due specifically to the intramuscular preparations. To overcome this difficulty, different categories are tabulated regarding the dose of steroid both before and during the study. It is noted that not all injections resulted in similar reactions in the same individual. Thus, only six? out of twenty injections of TActn or TDac in fours patients resulted in euphoria. In one of theseo individuals, the euphoria developed within 2 minuteso after an injection and was associated with a "hot" feeling in the abdomen, suggesting possible entranced of the steroid into the systemic circulation at the time of injection. This reaction lasted 3 hours. Nine out of fifteen injections in four other patients. resulted in a diuresis, usually beginning several $\overrightarrow{\vec{\omega}}$ hours after an injection and, at times, persisting ${ }^{\omega}$ for 3 to 4 days. When the period of anti-inflam- $-\frac{0}{3}$ matory improvement had run its course in these latter patients, those who had noted previous ankle? oedema found that some swelling returned at the time of worsening, only to be relieved again by $a \sim$ subsequent intramuscular injection of TActn oro TDac.

Marked weakness, nausea, and vomiting occurred $\vec{\rho}$ in one individual about 10 days after each of two $\mathbb{D}$ injections. These manifestations lasted 2 to 3 days $\mathbb{\Phi}$ and coincided with worsening of the joint findings $\overline{0}$

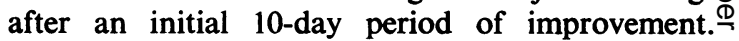
Another patient described marked weakness, tired $\overrightarrow{-} \vec{\bullet}$ ness, and dyspnoea after each of three injections? occurring simultaneously with the reappearance ôे increased synovitis following 10 days of satisfactory improvement. Two injections in this last patient were not followed by these symptoms. In each instance relief was obtained by another steroid $\bar{Q}$

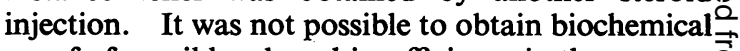
proof of possible adrenal insufficiency in these cases. $\frac{\hat{B}}{3}$ Electrolyte determinations of $\mathrm{Na}, \mathrm{K}$, and $\mathrm{Cl}$ per- $-\frac{3}{5}$ formed at the time of one of the episodes of vomiting in the first individual gave normal results.

The features of moon facies, ecchymoses, and $\frac{0}{2}$ hirsutism are also tabulated. There were fewero ecchymoses in two patients and less moon facies $\stackrel{3}{3}$. in three as compared with the previous period of oralo steroid therapy. In only one of three patients with less moon facies was the total daily dose of oral pluso intramuscular steroid less than the daily dose of oral steroid originally.

Epigastric burning developed in one case; this did not occur previously while the patient was taking . steroids by mouth. In another patient, there was 0 less epigastric burning during the period of intramuscular steroid therapy; in this patient it waso possible to lower the oral dose of dexamethasone, 0 but the total daily dose of steroid was still greater than the previous oral dose alone. The lowering? of the dexamethasone dose may have been respon- $\square$ sible for the decreased gastrointestinal symptoms. 
TABLE II

SIDE-EFFECTS OF INTRAMUSCULAR THERAPY WITH TActn AND TDac

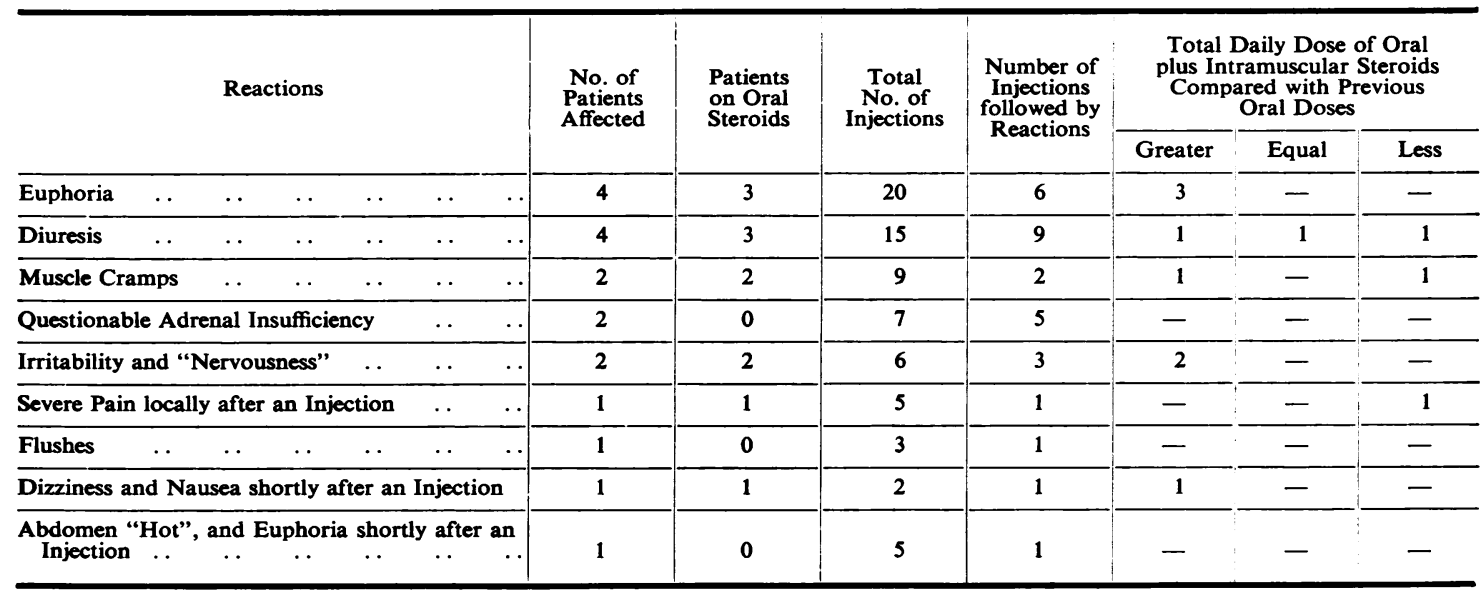

Reaction to Oral plus Intramuscular Steroid Therapy combined as compared with Oral Steroid Therapy Alone

\begin{tabular}{|c|c|c|c|c|c|c|c|c|c|c|c|}
\hline Ecchymoses .. & . & $\cdots$ & . & $\begin{array}{l}\text { More } \\
\text { Same } \\
\text { Fewer }\end{array}$ & $\begin{array}{l}\cdots \\
\cdots \\
\cdots\end{array}$ & $\begin{array}{l}1 \\
9 \\
2\end{array}$ & $\begin{array}{l}1 \\
9 \\
2\end{array}$ & $\begin{array}{r}2 \\
27 \\
7\end{array}$ & $\begin{array}{r}1 \\
- \\
-\end{array}$ & $\underline{-}$ & $\begin{array}{l}-1 \\
2\end{array}$ \\
\hline Moon Facies & . & $\cdots$ & $\cdots$ & $\begin{array}{l}\text { Greater } \\
\text { Same } \\
\text { Less }\end{array}$ & $\begin{array}{l}\cdots \\
\cdots \\
\cdots\end{array}$ & $\begin{array}{l}5 \\
6 \\
3\end{array}$ & $\begin{array}{l}5 \\
6 \\
3\end{array}$ & $\begin{array}{r}20 \\
18 \\
9\end{array}$ & $\begin{array}{l}5 \\
4 \\
1\end{array}$ & $\begin{array}{c}-1 \\
1\end{array}$ & $\begin{array}{l}- \\
1\end{array}$ \\
\hline Hirsutism $\quad \ldots$ & . & $\cdots$ & .. & $\begin{array}{l}\text { More } \\
\text { Same }\end{array}$ & $\begin{array}{l}\cdots \\
\cdots\end{array}$ & $\begin{array}{l}1 \\
2\end{array}$ & $\begin{array}{l}1 \\
2\end{array}$ & $\begin{array}{l}7 \\
8\end{array}$ & $\begin{array}{l}1 \\
1\end{array}$ & - & -1 \\
\hline Epigastric Burning & $\ldots$ & $\ldots$ & $\cdots$ & $\begin{array}{l}\text { Greater } \\
\text { Less }\end{array}$ & $\cdots$ & $\begin{array}{l}1 \\
1\end{array}$ & $\begin{array}{l}1 \\
1\end{array}$ & $\begin{array}{l}5 \\
2\end{array}$ & $\overline{1}$ & - & 1 \\
\hline Appetite & $\ldots$ & $\ldots$ & . & $\begin{array}{l}\text { Same } \\
\text { Improved }\end{array}$ & & $\begin{array}{l}1 \\
1\end{array}$ & $\begin{array}{l}1 \\
1\end{array}$ & $\begin{array}{l}3 \\
5\end{array}$ & 1 & - & $\overline{1}$ \\
\hline
\end{tabular}

Another patient had anorexia and lost $27 \mathrm{lb}$. while receiving oral triamcinolone in a maintenance dose of $8 \mathrm{mg}$. daily. During the period of intramuscular steroid therapy in this patient, no steroids were given orally; her desire for food returned, and she gained $7 \mathrm{lb}$. over a 3-month period.

Coincident with improvement was a decrease in the erythrocyte sedimentation rate in most patients tested. When the beneficial effects of the hormone were no longer present, the sedimentation rate usually rose again in conjunction with clinical worsening. Leucocytosis also appeared after many injections. No glycosuria was detected. Blood pressure elevation was not encountered with one possible exception; this patient had a history of hypertension before the study, but had had only one recorded blood pressure as a control (132/88). Subsequent values during the next 6 months of intramuscular steroid therapy averaged about 200/116. During this interval she had seven intramuscular injections of TActn and TDac. In the past month reserpine and chlorothiazide have been administered, and the blood pressure has fallen to $160 / 110$.

This intramuscular method of steroid administration was discontinued in nine patients for the following reasons: inadequate or no improvementfive; no further need for steroids-two; patient contact lost-two. Two of the five patients with unsatisfactory improvement had sufficient "irritability and nervousness" to also warrant the discontinuation of therapy.

\section{Discussion}

The aim of much research in the field of rheumatic diseases in the past several years has been to obtain steroids with greater anti-inflammatory action but with fewer side-effects. The most recent oral preparations, triamcinolone free alcohol (or triamcinolone), 6-methyl-prednisolone, and dexamethasone, offer certain advantages, but are associated with undesirable physiological reactions 
similar in many respects to those of the originally introduced anti-rheumatic hormones. No oral preparation combining a good anti-inflammatory response with relatively minor toxicity is yet available. The possibility of administering steroids intramuscularly in an attempt to obtain a satisfactory response with fewer or less severe sideeffects has been examined in this study. One investigator (West, 1958) has previously reported his experiences with intramuscular injections of prednisolone acetate in the treatment of rheumatoid arthritis. He administered the steroid at regular weekly intervals for periods of 16 to 45 weeks. His patients derived satisfactory improvement from this treatment, and, in some instances, had a decrease in gastric disturbances.

In this study $100-\mathrm{mg}$. doses of triamcinolone acetonide (TActn) and triamcinolone diacetate (TDac) gave marked systemic responses when injected intramuscularly. Relief of both subjective and objective rheumatic manifestations as regards pain, stiffness, range of motion, and degree of synovitis was very striking in the majority of instances with either of these preparations. The improvement usually persisted at a satisfactory level for 2 to 3 weeks after a single injection. The duration of improvement was usually greater following an injection of TActn than of TDac, the reverse being true significantly less often. Improvement from intramuscular injections of the triamcinolone derivatives was far greater than the benefit derived from intramuscular injections of hydrocortisone acetate (FAc) in 100- or 500-mg. doses.

In an attempt to explain the difference in response to these hormones, one might question the relative equality of the doses as used in this study. Was $100 \mathrm{mg}$. TActn equal to $100 \mathrm{mg}$. TDac? Were these latter doses equivalent to $500 \mathrm{mg}$. FAc? Triamcinolone and FAc when administered orally have an anti-inflammatory ratio of $5: 1$ when equal weights are compared; but there has been no evaluation of the relative effectiveness of these drugs when administered intramuscularly. The author has not found any description in the literature of the comparative efficacy of intramuscular doses of triamcinolone, TActn, and TDac. Preliminary studies (Zuckner, 1961) with the intra-articular administration of TActn and TDac revealed no significant difference in local anti-inflammatory response between the 20-mg. dose of TActn and the 25-mg. dose of TDac. However, the minimal effective dose of each preparation was not determined and, therefore, basic dose levels were not compared. Animal studies by Ringler, Bortle, Heyder, Monteforte, Perrine, and Ross (1959) indicated that TActn was 21 times as potent as hydrocortisone for liver glycogen deposi- $-\frac{D}{3}$ tion in rats when injected subcutaneously, and 167 times as potent as hydrocortisone when administered orally. Liver glycogen deposition was six $\Rightarrow$ times greater with subcutaneously administered $\stackrel{\text { ? }}{+}$ triamcinolone than with hydrocortisone, and $42 \%$ times greater with oral administration than with $\frac{\overline{\bar{D}}}{\overline{0}}$ hydrocortisone. These values for triamcinolone $\frac{\bar{\sigma}}{\odot}$ were lower than those previously reported byळ Perrine, Bortle, Heyder, Partridge, Ross, and Ringler (1959). When thymus involution in rats $\vec{O}$ was studied by Ringler and others (1959), TActn:injected subcutaneously was 29 times more potent $\vec{\omega}$ than hydrocortisone, and 75 times more potent than hydrocortisone when both drugs were given orally. It is, therefore, possible that the differentio anti-rheumatic responses to the intramusculari $\omega$ injection of TActn, TDac, and FAc could bei explained at least in part by inecuualities of dosage + since relative dosages have not been clearly evalu-은 ated. Other factors, however, have to be con- sidered.

It is interesting to speculate on the significantly $\frac{\mathbb{D}}{\mathbb{C}}$ greater duration of improvement which followed 3 intramuscular injections of the triamcinolone derivatives as compared with FAc. Is this greater $\vec{\bullet}$ improvement due to a depot effect of TActn amdo TDac, whereby the hormone is slowly released. into the circulation over the period of sustainedo improvement? This suggested depot mechanism requires evaluation, but its substantiation may haveō to await the availability of isotopically labelled\% triamcinolone or, perhaps, an adequate method of measuring blood levels of triamcinolone in order to $\overrightarrow{\vec{O}}$ follow the absorption of the injected material. A3 partial answer may be derived by studying the blood levels of 17-hydroxycorticoids after an injection of TActn or TDac. One such experiment (Zuckner, 1961, unpublished) was performed in a rheumatoid? patient after a $100-\mathrm{mg}$. intramuscular injection of TDac. This subject did not show an anti-inflammatory response to the injection. An initial sup-윽 pression of the 17-hydroxycorticoid level in the blood was noted within 4 hours, with a subsequent 5 return to normal values 7 days later. The adrenal cortex was evidently suppressed for approximately 7 days, but interpreting this in terms of absorption $N$ rates is hazardous.

Another possible explanation of the greater improvement with TActn and TDac might be ${ }^{\omega}$ related to the initial massive steroid dose employed. This would imply that a sudden high level of hormone in the blood would have a greater physiological effect than a prolonged lower level. + This has proved to be a vital factor in certain 
experimental conditions as, for example, in the production of Alloxan diabetes in rats (Lazarow, 1946; Gomori and Goldner, 1945). A sudden high blood level of the agent might cause a greater effect in cells that have a greater avidity for the material than in other cells in the body. The inflammatory cells in synovial tissue probably would have an increased permeability and so might absorb large molecules much more rapidly. In order to get enough steroid into inflamed cells, a high concentration for a short time might be more apt to overcome the cell wall barrier than a more prolonged lower level. Another consideration would be that, if the agent is inactivated rapidly, it must be able to act before inactivation occurs; higher blood levels would then be more likely to provide the opportunity for the action to take place than prolonged lower blood levels.

This intramuscular method of administering steroids, in particular TActn and TDac, offered certain advantages and partially satisfied the criteria for a more effective anti-inflammatory drug. In approximately 25 per cent. of the patients the disease was controlled on a smaller daily maintenance intramuscular dose of steroid than that given orally before this study. Six individuals who had taken steroids orally for prolonged periods had better and more sustained relief from the intramuscular injections of TActn and TDac, and were maintained on this latter therapy alone. In eight others, the combination of oral and intramuscular steroid therapy proved more beneficial than the oral medication by itself; the oral dose in these patients was gradually decreased, but was supplemented by occasional intramuscular injections of TActn or TDac. Nine patients who had never taken steroids previously were adequately controlled by intramuscular injections of TActn and TDac. Toxicity was generally the same as that seen with previous hormone therapy. In two patients there were fewer ecchymoses and, in three, less moon facies during the period of parenteral therapy. Those who developed a greater degree of moon facies and more ecchymoses while on the study were receiving relatively larger daily doses of steroid and would, therefore, have been expected to show more of these changes. Euphoria was the only complication in slight excess as compared with the previous control period of oral steroid medication, but this was not severe enough to require discontinuation of treatment. The period of observation was not sufficiently long to study other reactions associated with steroid therapy, such as osteoporosis and peptic ulceration. Further evaluation will be necessary to determine the true incidence of toxicity. These preliminary findings suggest that fewer side-effects occur in some cases with this intramuscular method of administration than with oral administration.

\section{Summary}

Triamcinolone acetonide (TActn) and triamcinolone diacetate (TDac) were injected intramuscularly in 100-mg. doses into 36 patients with rheumatoid arthritis. There were 68 injections of the acetonide derivative and 44 of the diacetate. Satisfactory improvement lasted an average of 20.2 days after an injection of triamcinolone acetonide and $16 \cdot 2$ days after an injection of triamcinolone diacetate. The results from this form of treatment compared very favourably with those from previous oral steroid administration, and in approximately 25 per cent of cases was more satisfactory. Undesirable side-effects were possibly slightly diminished, but a further long-term study would be required for final evaluation.

\section{REFERENCES}

Gomori, G., and Goldner, M. G. (1945). Proc. Soc. exp. Biol. (N.Y.), 58, 232.

Lazarow, A. (1946). Ibid., 61, 441.

Perrine, J. W., Bortle, L., Heyder, E., Partridge, R., Ross, E. K., and Ringler, I. (1959). Endocrinology, 64, 437.

Ringler, I., Bortle, L., Heyder, E., Monteforte, A., Perrine, J. W., and Ross, E. K. (1959). Proc. Soc. exp. Biol. (N.Y.), 102, 628.

Steinbrocker, O., Traeger, C. H., and Batterman, R. C. (1949). J. Amer. med. Ass., 140, 659.

West, H. F. (1958). Ann. rheum. Dis., 17, 273.

Zuckner, J. (1961). Unpublished observations.

Traitement de l'arthrite rhumatismale par des injections intramusculaires d'acétonide de triamcinolone et de diacétate de triamcinolone

\section{RÉSUMÉ}

On administra par voie intramusculaire l'acétonide de triamcinolone (TActn) et diacétate de triamcinolone (TDac) en doses de $100 \mathrm{mg}$. à 36 malades atteints d'arthrite rhumatismale. En tout, on donna 68 injections du dérivé acétonide et 44 injections du dérivé diacétate. Une amélioration satisfaisante persista en moyenne pendant 20,2 jours après l'injection d'acétonide de triamcinolone et pendant 16,2 jours après l'injection de diacétate de triamcinolone. Les résultats de cette forme de traitement ne le cédent en rien à ceux obtenus auparavant par l'administration orale des stéroïdes, et dans 25 pour cent des cas ils furent plus satisfaisants. Les effets secondaires furent peut-être moins accusés, mais des recherches ultérieures seraient nécessaires pour une évaluation finale. 
Tratamiento de la artritis reumatoide por administración intramuscular de acetonido de triamcinolona y de diacetato de triamcinolona

\section{Sumario}

Se administraron intramuscularmente acetonido de triamcinolona (TActn) y diacetato de triamcinolona (TDac) a dosis de $100 \mathrm{mg}$. a 36 enfermos con artritis reumatoide. Fueron practicadas 68 inyecciones de derivado acetonido y 44 del diacetato. La satisfactoria mejoría perduró un termino medio de 20,2 días después de la inyección de acetónido de triamcinolona y 16,2 días después de la de diacetato de triamcinolona. Los resultados de esta forma de tratamiento no fueron inferiores a los obtenidos anteriormente por administration oral de esteroides, y en un $25 \%$ de los casos fueron más satisfactorios. Efectos colaterales indeseables fueron quizás algo menores, pero para una valoración final son necesarios estudios ulteriores a largo plazo. 